\title{
Article \\ How Agriculture, Connectivity and Water Management Can Affect Water Quality of a Mediterranean Coastal Wetland
}

\author{
Lucía Vera-Herrera $^{1, *\left(\mathbb{D}, \text { Susana Romo }^{2} \text { and Juan Soria }\right.}{ }^{3 \oplus \mathbb{C}}$ \\ 1 Food and Environmental Safety Research Group, University of Valencia (SAMA-UV), Desertification Research \\ Centre-CIDE (CSIC-UV-GV), Moncada-Naquera Road Km 4.5, 46113 Moncada, Spain \\ 2 Department of Microbiology and Ecology, Campus Burjassot, University of Valencia, 46100 Burjassot, Spain; \\ susana.romo@uv.es \\ 3 Campus Paterna, Cavanilles Institute of Biodiversity \& Evolutionary Biology (ICBiBE), University of Valencia, \\ 46980 Paterna, Spain; juan.soria@uv.es \\ * Correspondence: vehelu@uv.es
}

check for

updates

Citation: Vera-Herrera, L.; Romo, S.;

Soria, J. How Agriculture,

Connectivity and Water Management

Can Affect Water Quality of a

Mediterranean Coastal Wetland.

Agronomy 2022, 12, 486

https://doi.org/10.3390/

agronomy12020486

Academic Editor:

Aliasghar Montazar

Received: 5 January 2022

Accepted: 14 February 2022

Published: 16 February 2022

Publisher's Note: MDPI stays neutral with regard to jurisdictional claims in published maps and institutional affiliations.

Copyright: (C) 2022 by the authors. Licensee MDPI, Basel, Switzerland. This article is an open access article distributed under the terms and conditions of the Creative Commons Attribution (CC BY) license (https:// creativecommons.org/licenses/by/ $4.0 /)$.

\begin{abstract}
The Natural Park of Albufera (Valencia, Spain) is an important Mediterranean coastal wetland that suffers continuous environmental effects from human activities and water uses, mainly related to agriculture and urban/industrial sewage discharges. The aim of this research was to assess the water quality of the different aquatic environments of this wetland, taking into account the connection between them, the agricultural impact and the management of irrigation water. The UE Water Framework Directive was followed in order to evaluate the ecological and trophic status of water systems. Spatial approaches were used to integrate physicochemical data into GIS vector layers to map the more problematic points of pollution. The results showed a globally eutrophic system with poor ecological potential. The wetland is nutrient-overloaded during the entire rice cultivation period. Good-quality water inputs are deficient, since the river network already has high levels of nutrients and pollutants, especially in the northern area, where river water is mixed with inappropriate effluents from wastewater treatment plants. Agriculture and water management affected the area intensively up to the Albufera lake, modulating most of the studied variables. The information gathered here can help to optimize the global study and management of the coastal Mediterranean wetlands, which are highly linked to agriculture.
\end{abstract}

Keywords: water quality; agro-ecological wetland; irrigation; nutrients; ecological status

\section{Introduction}

The impact of human activity on nature is already known to constitute a new geological epoch, the Anthropocene [1,2]. The main current environmental problems, such as climate change, the loss of biodiversity, water pollution and desertification, are rooted in the impact of populations on natural resources and ecosystems. Wetlands are among the most important freshwater aquatic ecosystems, although they are also among the most vulnerable on the planet. They are considered indispensable for the ecosystem services they provide to humanity, including natural reserves of fresh water, the supply of essential foods, flood control and groundwater recharge and discharge, as well as being natural areas of great biological diversity [3]. Furthermore, more recently, many studies have confirmed that wetlands play a significant role in the permanent sequestration of carbon, acting as important buffers to climate change [4-8]. However, despite their importance, these aquatic ecosystems are currently at risk of disappearing due to the overexploitation of their resources and the continuous anthropogenic pressure to which they are subjected. Major anthropogenic activities include the conversion of natural wetlands into land for intensive agriculture or for industrial and urban development. As a result, it is now known that from 1970 to 2015 , about $35 \%$ of the natural wetlands have disappeared and $36 \%$ of coastal wetland-dependent species have decreased. In addition, the quality of wetland water bodies 
has experienced negative trends due to nutrient run-off from intensive agriculture and the release of urban pollutants from wastewater treatment plants (WWTPs) and untreated wastewater discharges $[9,10]$.

In this context, Mediterranean coastal wetlands are examples of the fragility of these areas. Ecologically, these wetlands are recognized as biodiversity hotspots, especially for birds, serving as a refuge during migratory processes. In addition, they have a high economic value, as they are linked to important economic activities such as fishing, salt production and rice farming [11,12], but in contrast they have undergone several anthropogenic effects $[13,14]$. These wetlands have experienced dramatic changes in recent years, which could worsen in the coming decades [15-17]. Climate change has increased mean temperatures by $1.4^{\circ} \mathrm{C}$ in the region since the preindustrial period and has also increased the frequency of severe drought events, contributing to the desertification of these natural areas [11,18]. Overall, it is estimated that $50 \%$ of Mediterranean wetlands have been lost in the last century [19]. Moreover, they all depend on complex hydrological cycles, determined mainly by groundwater and irrigation networks [11]. All these factors imply the complexity of managing of these ecosystems, which makes challenging to develop monitoring, conservation and environmental restoration strategies $[9,11,20]$.

In recent decades, many environmental agencies around the world have established policy instruments to protect inland, transitional and coastal waters, as well as procedures to evaluate their status based mainly on large-scale assessments [9,21]. In 1991, the European Union (EU) developed the Nitrates Directive (91/676/EEC), which deals with pollution caused by nitrates from agricultural sources. It requires Member States to identify polluted waters and "Nitrate Vulnerable Zones" and establish Codes of Good Agricultural Practice and effective Action Programmes [22]. That same year, the EU developed the Urban Wastewater Treatment Directive (91/271/EEC), which sets out a number of obligations in relation to collection systems, with further restrictions in areas sensitive to eutrophication [23]. In 2000, the EU introduced the most ambitious and influential ecological legislative framework, the Water Framework Directive (2000/60/EC). This European Directive, based on a new approach to water policy, had as its first objective the achievement of a good status for EU waters by 2015 [24], and clearly involves the assessment, protection and restoration of wetlands as part of its purpose. This directive, together with the Birds Directive (2009/147/EC) and Habitats Directive (92/43/EEC), aim to achieve the sustainable use of wetlands resources and the conservation of their ecological functions and attributes [24].

The trophic state index is commonly used to determine the trophic degree of water bodies [25]. The Water Framework Directive has water quality indicators that also take into account the complexity of each aquatic ecosystem: the human pressures to which they are exposed and the spatio-temporal variation of its physicochemical characteristics, among other features [21,26-28]. The most important index is the ecological potential: "an expression of the quality of the structure and functioning of aquatic ecosystems associated with surface waters" [24]. This approach is based on thresholds assigned to specific physicochemical, hydrological and biological indices [29] and allows the assessment of the chemical status of water bodies and reversing deterioration trends.

In addition, recently new tools and methodologies have emerged for the environmental assessment of wetlands, such as remote sensing [30], which can evaluate the state of water bodies at spatial and temporal levels at different resolutions, and algorithms have been developed to measure limnological parameters [31-34]. Moreover, geographic information systems (GIS) have allowed new approaches in recent years different environmental compartments incorporating into environmental studies (known as landscape functional areas, LFAs) [35], as well as the hydrological connectivity between zones. The modeling approach [36] is often specific for an aquatic system [37], but can simulate wetland characteristics under different scenarios, frequently related to climate change [26,38-40].

The Natural Park of Albufera (Valencia, Spain) is an important Mediterranean coastal wetland (RAMSAR and NATURA 2000 site), which includes the largest Iberian coastal 
lagoon. This wetland, the Doñana National Park and the Ebro Delta Natural Park represent three relevant natural reserves and areas for Spanish rice production. The present work evaluates for the first time the water quality of the different aquatic environments of this Mediterranean wetland, taking into account their connectivity, the agricultural impact and the management of irrigation water. The study will assess the current ecological status of the wetland water systems depending on the different agricultural activities and the origin of the irrigation water. The main aims of our study are to (1) analyze the differences in the water quality of the aquatic ecosystems at the beginning and the end of rice cultivation, (2) study the spatial heterogeneity of the variables using GIS approaches to assess water quality differentially according to agricultural activities in the catchment area and in relation to the management of the irrigation water and (3) determine the ecological and trophic status of the water systems of the wetland. The results can contribute to improving global databases on Mediterranean coastal wetlands, as well as helping to develop adequate management and assessment plans for these complex ecosystems.

\section{Methods}

\subsection{Study Area}

The study area is an extensive zone that includes part of the main rivers, irrigation channels and inflows and outflows related to the Natural Park of Albufera, which is located in eastern Spain $\left(39^{\circ} 20^{\prime} \mathrm{N}, 0^{\circ} 21^{\prime} \mathrm{W}\right)$ (Figure 1A). It is delimited by the rivers Turia (to the north) and Jucar (to the south). This wetland is near the city of Valencia and it is surrounded mostly by rice fields, as well as some industries. For this reason, the area presents a complex relationship between its intrinsic natural importance and human activities. The wetland has an area of $210 \mathrm{~km}^{2}$ and is an important coastal Mediterranean wetland, protected by the Ramsar Convention and the European Habitat List NATURA 2000 [41].

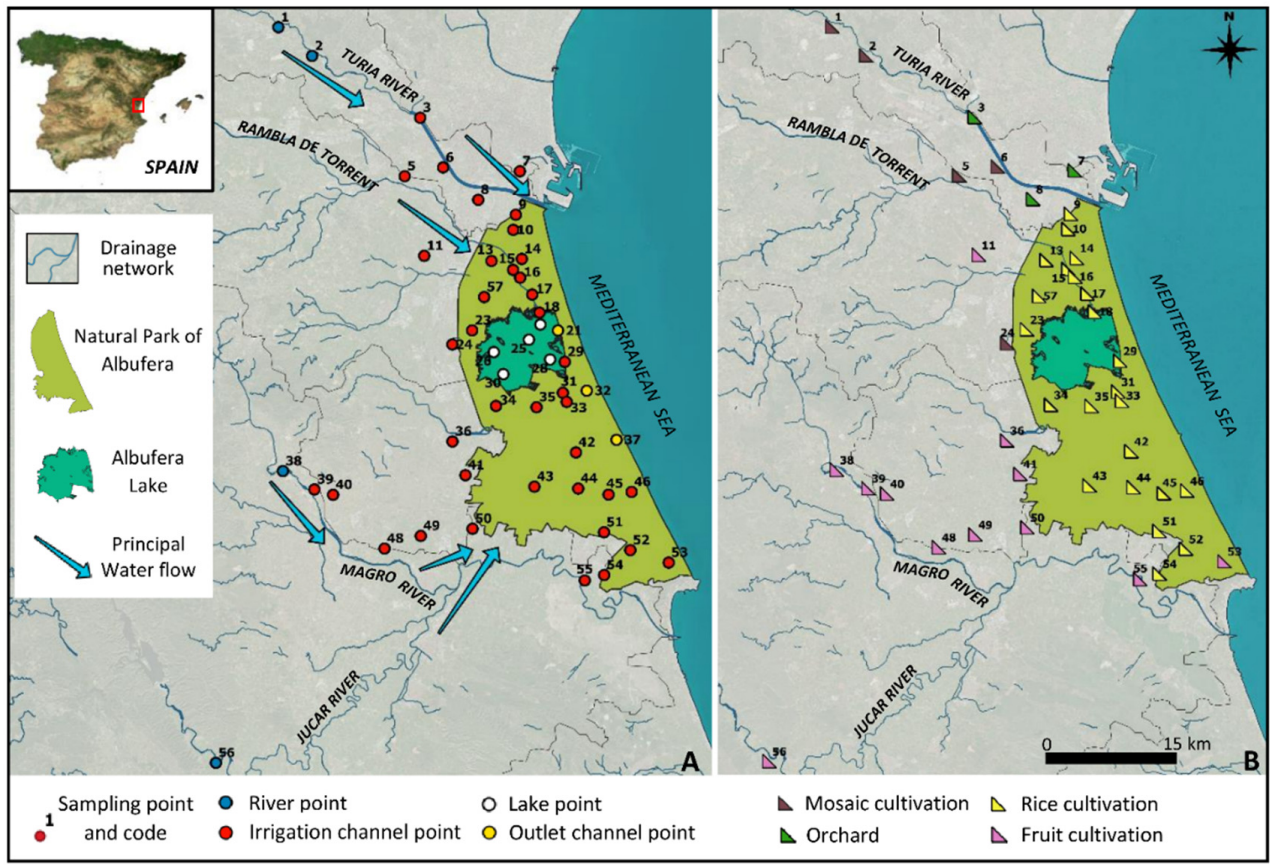

Figure 1. Study area with the principal river networks, the limit of the Natural Park of Albufera and the area of Albufera Lake. (A) Sampling points classified according to their corresponding aquatic habitats and arrows showing the principal water flow to the natural park. (B) Sampling points classified according to the agricultural activity carried out in their vicinity. Base image: OrtoPNOA 2018 CC-BY 4.0 scne.es. 
In the study area there are three main types of crops (Figure 1B). On the one hand, the rainfed farming that once covered the western lands has been replaced by crops of fruit trees, especially citrus [42]. Since 1979, this area has been crossed from south to north by the Jucar-Turia Canal, which was designed to transport water from the Jucar to the Turia River and supply water to all the irrigated fields on both sides of the canal [43]. On the other hand, we can also find vegetable crops located near small towns in the border of the natural park. Finally, the farming activity of greatest interest to our study is rice cultivation, due to the fact that it has developed practically throughout the entire extent of the natural park, covering $73 \%$ of its surface area [21]. To achieve the effective irrigation of rice paddies, the entire study area supports a dense structure of overland artificial canals for the irrigation of $59.7 \mathrm{~km}$ and a density of $323 \mathrm{~m} / \mathrm{km}^{2}$ that connect the water from the Rivers Jucar and Turia with the crops [44]. However, this complex irrigation system connects many of the canals with the sewerage infrastructures of the surrounding municipalities, receiving industrial and urban discharges. These sewage effluents are considered sources of nutrients $[45,46]$ and emerging pollutants, such as perfluoroalkyl substances, organophosphorus flame retardants and pharmaceuticals and personal care products, among others [47-50].

In the center of the Natural Park is the Albufera Lake, a shallow (mean depth of $1 \mathrm{~m}$ ) and oligohaline (salinity 1-2\%) lagoon, that represents the largest Spanish coastal lake, with a surface area of $23.2 \mathrm{~km}^{2}$, covering approximately $11 \%$ of the wetland area [51,52]. The hydrology of the lake combines natural contributions (seasonal rainfall) with complex water management for rice cultivation [53]. The lake's hydrological cycle has two periods of low water renewal from November to December and from April to September during rice sowing and growing. The higher lake water renovation takes place between January and March after the emptying of the paddy fields and by September-October after harvesting $[34,51,54]$. The lake water level is regulated by three artificial outlet canals, which flow into the Mediterranean Sea [51]. The lake has been eutrophic since the 1970s due to the urban and industrial discharges and nitrogen-rich effluents from rice fields. These discharges turned the lake rapidly into a turbid microalga-dominated site, whereas the richness of aquatic plants and fauna severely decreased after the first half of 20th century [51,55-58]. The plans for the reduction of nutrient-rich sewage discharges over the last three decades have failed to change the trophic state of the lake $[51,59,60]$. More detailed information about the lake is given elsewhere [51,61].

\subsection{Sampling Points and Water Collection}

A total of 51 water bodies were studied, located in four different aquatic systems: in sections of the rivers Turia, Jucar and Magro; in the most important ditches that irrigate the Natural Park; in the Albufera Lake and in the outlet canals that connect the lake with the Mediterranean Sea (Figure 1A). All these water systems were sampled twice, at the start and the end of rice cultivation in the wetland, during May and June 2019 and September and October 2019, respectively. A total of 100 samples were studied. During the first sampling campaign, 51 freshwater samples were taken, whereas in the second one there were 49 samples, because two irrigation channel points were dried.

Sampling points were classified for further analysis (Supplementary Material, Table S1). Firstly, they were identified with their corresponding aquatic habitat: rivers, irrigation channels or lake points (including outlet canals) (Figure 1A). Secondly, thanks to the digital layer "Corine Land Cover 2018 Classification" provided by the Copernicus Global Land Service (CGLS) [62], each sampling point was classified according to the agricultural activity carried out in its vicinity. The activities identified were traditional orchards, mosaic cultivation, rice cultivation (carried out inside the Natural Park) and fruit tree cultivation (Figure 1B). The water samples taken from the lake, outlet canals and tancats were excluded from this classification as they are not associated with any crop. Finally, the sampling points were also classified according to their irrigation zones [63] (Figure 2). The irrigation zones sampled were the following: Mislata, Benager and Faitanar (included in a single zone called "Huerta Oeste"), Favara, Oro, Acequia Real del Júcar (abbreviated as ARJ), 
Sueca and Cullera. The Turia and Magro river points are not located in any irrigation zone and were classified separately, as happened with the lake points, also including the tancats.

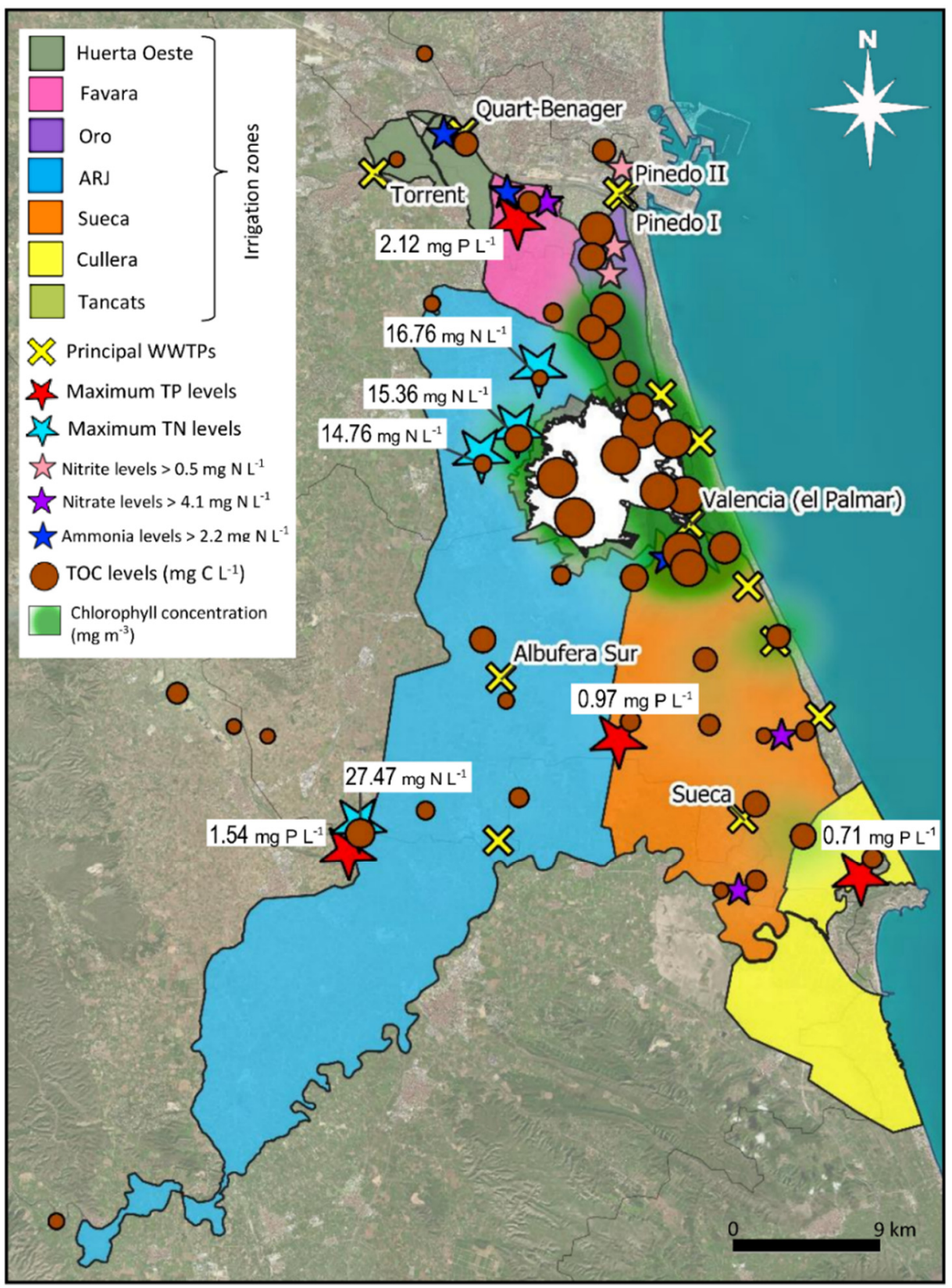

Figure 2. Agricultural (irrigation zones) and urban contextualization of the study area and spatial representation of the maximum levels of $\mathrm{TP}, \mathrm{TN}$, nitrite, nitrate and ammonium nitrogen together with the average concentrations of TOC and phytoplanktonic chlorophyll a. Base image: OrtoPNOA 2018 CC-BY 4.0 scne.es.

Water samples were taken in clean polyethylene bottles (capacity $0.5 \mathrm{~L}$ and $1 \mathrm{~L}$ ). At each sampling point, the bottles were pre-rinsed with the sample water three times. The bottles were maintained at $4{ }^{\circ} \mathrm{C}$ until reaching the laboratory. Once there, samples were filtered through $0.45 \mu \mathrm{m}$ glass microfiber GF/F filters (Whatman, UK) and the filters were stored in glass tubes in the dark at $-20{ }^{\circ} \mathrm{C}$ for pigments extractions. 


\subsection{Water Analyses}

Turbidity, $\mathrm{pH}$ and conductivity were measured in situ directly from the water bodies whenever possible, using an AquaFluor ${ }^{\circledR}$ Handheld Turbidimeter from Turner Designs (San Jose, CA, USA), and a $\mathrm{pH}$ and $\mathrm{EC}$ waterproof testers from Hannah Instruments ${ }^{\circledR}$ (Woonsocket, RI, USA), respectively. When direct data collection was not possible, $1 \mathrm{~L}$ of water was taken from the sampling point, using clean polyethylene beakers, pre-washed with the sample water three times. Organic matter, dissolved inorganic nitrogen (DIN: nitrate, nitrite and ammonium nitrogen) and phosphorus concentrations (SRP) were analyzed according to the standard methods [64]. For the analyses of total inorganic carbon (TIC), total organic carbon (TOC) and total nitrogen (TN), unfiltered water samples were first treated in an ultrasonic bath for $15 \mathrm{~min}$ in order to achieve an optimal mixture of dissolved and particulate components. Then, determinations were made using a carbon and nitrogen analyzer (a TOC-V combustion catalytic oxidation/NDIR system in combination with an ASI-V sampler from Shimadzu; Kyoto, Japan) according to ISO-CEN EN 1484:1997 [65]. Specifically, TIC was detected as $\mathrm{CO}_{2}$ using a non-dispersive infrared detector (NDIR), from the acidification of the sample and its subsequent catalytic oxidation. After removal of the TIC fraction from the sample, TOC was determined as non-volatile organic carbon (NPOC) through catalytic oxidation of the remaining carbon (TOC by acidification/sparging method). TN was decomposed to nitrogen monoxide using a thermal decomposition catalyst and detected using a chemiluminescence detector. The total dissolved organic carbon (DOC) and the total dissolved nitrogen (DN) were analyzed in filtered water samples following the same methods described above, except for the previous step with the ultrasonic bath. Total phosphorus (TP) concentrations were determined in unfiltered samples by means of the molybdate-blue method after acid persulfate digestion [66]. Particulate phosphorus (Ppart) and dissolved organic nitrogen (DON) were calculated by subtracting the respective SRP portion from the TP concentration, and subtracting the DIN portion from the DN concentration, respectively. The total carbon (TC) was calculated as the sum of NPOC and TIC. Chlorophyll $a$ and carotene were extracted with acetone $90 \%$ and determined according to APHA [64] and Jeffrey and Humphrey [67]. LOD and LOQ information is provided in Table S2 (Supplementary Material).

\subsection{Water Quality Assessment}

The average of each study variable per sampling point was calculated and subjected to different evaluations. The trophic statuses of water bodies were calculated according to Chlorophyll $a$, TP [68] and TN levels [69]. The ecological potential was studied based on biological and physicochemical quality elements [24,70]. For this ecological assessment of water bodies, the sampling points were first classified according to their water body typology, applying the Water Framework Directive and following the requirements of Decree $1 / 2016$. Information about the water body typologies included in our study is available in Table S1 (Supplementary Material).

All the results obtained were integrated into different digital vector layers using QGIS (3.12) software. The maps developed were delimited according to surface waters distribution, combining natural and irrigation networks. The GIS covers allowed us to carry out studies using different spatial approaches.

\subsection{Meteorological Data}

The daily and monthly meteorological data recorded in the basin during the study period (May-June and September-October 2019) were obtained from two different stations: one located in the city of Valencia (Penya-Roja station) and another located on the shore of the Albufera Lake (Tancat de la Pipa station) [71].

\subsection{Statistical Analyses}

Univariate statistical analyses were used to obtain descriptive statistics for each variable and sampling period and for the average values of the variables. The assumptions 
of normality of the data were checked prior to statistical analyses, and non-parametric tests were used when variables were not normally distributed (Shapiro-Wilk test, $p<0.05$ ). Student's $t$-test was used to identify statistically significant differences between the two sampling periods and the unequal variance $t$-test was used as an alternative when variances between pairs of data were very different. The average of each study variable per sampling point was then calculated, transformed and subjected to a principal components analysis (PCA) using the correlation matrix. Multidimensional clustering using Euclidean distance was calculated to detect relationships between groups of points and main driving factors. Spearman's rank-order correlation coefficient was used to obtain the correlation between study variables. In addition, the average data were subjected to some Kruskal-Wallis and PERMANOVA tests (with the Mann-Whitney post hoc test) to identify significant differences between the different clustering factors (zoning study). Analyses were performed using PAST (3.22) software [72].

\section{Results}

The study area has a Mediterranean climate. During the period of May-June 2019, the average temperature recorded was $20.4{ }^{\circ} \mathrm{C}$, with a standard deviation of $2.9^{\circ} \mathrm{C}$; an absolute daily maximum of $31.6^{\circ} \mathrm{C}$ and minimum of $10.2{ }^{\circ} \mathrm{C}$. The total precipitation recorded was $26.6 \mathrm{~mm}$, with an absolute daily maximum of $7.6 \mathrm{~mm}$. During the second study period, September-October 2019, the average temperature recorded was $22.1{ }^{\circ} \mathrm{C}$, the standard deviation was $2.8^{\circ} \mathrm{C}$; the absolute daily maximum was $33.7{ }^{\circ} \mathrm{C}$ and the minimum was $12.0^{\circ} \mathrm{C}$. The total precipitation recorded was $247.2 \mathrm{~mm}$, with an absolute daily maximum of $52.3 \mathrm{~mm}$. In accordance with the climate of the study area, the highest rainfall was recorded during the second study period, during autumn, when half of the total rainfall of the year is usually recorded. No extraordinary drought events were recorded.

\subsection{Effects of Rice Cultivation on Water Quality}

Table S3 (Supplementary Material) shows the results obtained for the variables analyzed in all the water bodies at different phases of rice cultivation. In general, the values ranged similarly at the start and the end of the cultivation. By considering the whole study system (referred to henceforth as the "wetland") we found only significant differences in $\mathrm{pH}, \mathrm{EC}$, alkalinity and TC $(p<0.05)$ (Figure 3$)$, with no significant changes observed in photosynthetic pigment concentrations or nutrient levels $(p>0.05)$. The rivers samples only increased their $\mathrm{pH}$ significantly and had a significant carbon decrease (TIC and TC) $(p<0.05)$ (Figure 3). The irrigation canals studied experienced the same significant changes as the wetland system and a decrease in ammonium nitrogen (NH4-N) concentrations $(p<0.05)$ (Figure 3). The lake was the aquatic ecosystem that experienced the greatest changes during the cultivation period, with alkalinity, $\mathrm{pH}, \mathrm{TIC}$ and TC increasing significantly $(p<0.05)$ (Figure 3$)$. In contrast, the lake experienced a significant decrease in turbidity, EC, pigment concentrations and some nutrient levels $(p<0.05)$ (Figure 3$)$ as a result of the dilution of the lake water after the emptying of the rice fields before harvesting.

\subsection{Global Wetland Approach}

For an evaluation of the wetland, the average values of the physicochemical and biological variables were studied per sampling point. In relation to the physical variables, turbidity reached a mean value of $11.57 \mathrm{NTU} \pm 1.46$ and the EC reached a mean of $1550.3 \mu \mathrm{S} \mathrm{cm}^{-1} \pm 86.7$ (Table 1). Regarding dissolved nutrients, in general, the mean concentrations of NH4-N and nitrite nitrogen were relatively moderate (Table 1). Nitrate nitrogen reached higher concentrations in water systems, with a mean concentration of $1.947 \mathrm{mg} \mathrm{N} \mathrm{L}^{-1} \pm 0.188$ (Table 1). Phosphate concentrations were significant and reached a maximum value of $1.451 \mathrm{mg} \mathrm{P} \mathrm{L}^{-1}$ (Table 1). The mean concentrations of TN, TP and TC were $6.30 \mathrm{mg} \mathrm{N} \mathrm{L}^{-1} \pm 0.67,0.226 \mathrm{mg} \mathrm{P} \mathrm{L}^{-1} \pm 0.05$ and $35.82 \mathrm{mg} \mathrm{C} \mathrm{L}^{-1} \pm 1.48$, respectively (Table 1). About $60-90 \%$ of TN was dissolved forms and about $50-90 \%$ of TP was particulate. TC was mainly inorganic, with TIC reaching a mean concentration of 
$29.90 \mathrm{mg} \mathrm{C} \mathrm{L}^{-1} \pm 1.43$ (Table 1). In relation to the biological variables, Chl-a and carotenes reached a mean concentration of $25.3 \mathrm{mg} \mathrm{m}^{-3} \pm 3.9$ and $11.2 \mathrm{mg} \mathrm{m}^{-3} \pm 1.8$, respectively (Table 1).

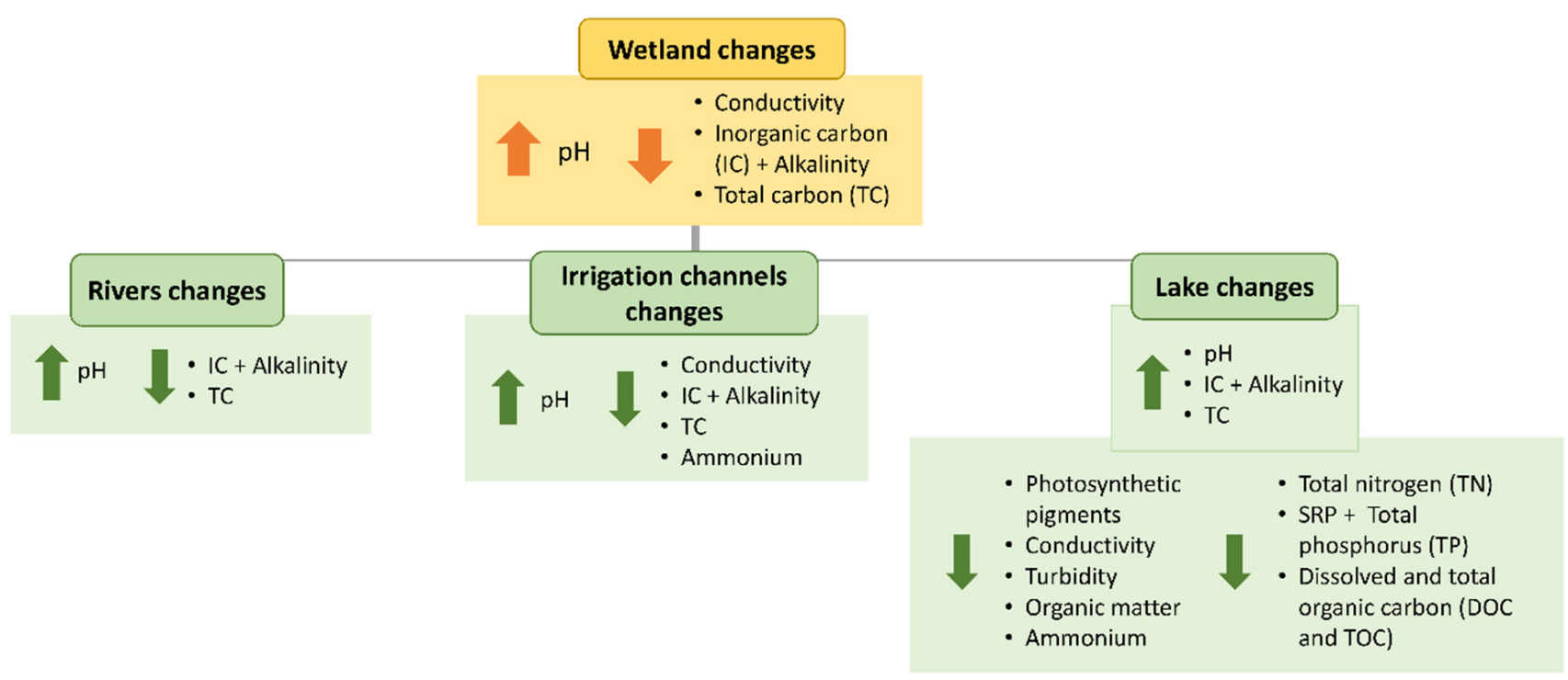

Figure 3. Statistically significant differences observed in the aquatic systems when comparing the beginning and ending of the rice cultivation period according to Student's $t$-test results $(p<0.05)$.

Table 1. Mean, standard error, maximum and minimum values of the physico-chemical and biological variables studied in the water bodies during rice cultivation (May to October 2019), together with the results obtained for the Kruskal-Wallis tests to observe differences between (A) aquatic habitats, (B) agricultural activities and (C) irrigation zones. Probabilities are: ${ }^{*} p<0.05,{ }^{* *} p<0.01$; ns $=$ not significant differences.

\begin{tabular}{|c|c|c|c|c|c|c|c|}
\hline Variable & Mean & SE & Maximum & Minimum & $\underset{p \text {-Value }}{\text { (A) }}$ & $\begin{array}{c}\text { (B) } \\
p \text {-Value }\end{array}$ & $\begin{array}{c}\text { (C) } \\
p \text {-Value }\end{array}$ \\
\hline Turbidity (NTU) & 11.57 & 1.46 & 50.80 & 0.60 & ns & $* *$ & ns \\
\hline $\mathrm{pH}$ & 7.86 & 0.04 & 8.80 & 7.30 & ns & $*$ & ns \\
\hline Conductivity $\left(\mu \mathrm{S} \mathrm{cm}{ }^{-1}\right)$ & 1550.3 & 86.7 & 5136.0 & 663.0 & $* *$ & $*$ & $* *$ \\
\hline Organic matter $\left(\mathrm{mg} \mathrm{L}^{-1}\right)$ & 1.240 & 0.095 & 3.449 & 0.340 & $* *$ & $* *$ & $* *$ \\
\hline Ammonium nitrogen $\left(\mathrm{mgN} \mathrm{L}^{-1}\right)$ & 0.551 & 0.123 & 3.920 & 0.005 & $* *$ & $* *$ & $* *$ \\
\hline Nitrite nitrogen $\left(\mathrm{mgN} \mathrm{L}^{-1}\right)$ & 0.141 & 0.021 & 0.600 & 0.001 & $* *$ & $* *$ & $* *$ \\
\hline Nitrate nitrogen $\left(\mathrm{mgN} \mathrm{L}^{-1}\right)$ & 1.947 & 0.188 & 4.705 & 0.013 & ns & $*$ & $* *$ \\
\hline Dissolved inorganic nitrogen (DIN; $\mathrm{mgN} \mathrm{L}^{-1}$ ) & 2.639 & 0.247 & 7.155 & 0.358 & $*$ & $* *$ & $* *$ \\
\hline Dissolved organic nitrogen $\left(\mathrm{DON} ; \mathrm{mgN} \mathrm{L}^{-1}\right)$ & 2.972 & 0.675 & 26.075 & 0.021 & ns & * & ns \\
\hline Dissolved nitrogen $\left(\mathrm{DN} ; \mathrm{mgN} \mathrm{L}^{-1}\right)$ & 5.61 & 0.67 & 26.51 & 0.70 & $* *$ & ns & ns \\
\hline Total nitrogen $\left(\mathrm{TN} ; \mathrm{mgN} \mathrm{L}^{-1}\right)$ & 6.30 & 0.67 & 27.47 & 1.07 & ns & * & ns \\
\hline Soluble reactive phosphorus (SRP; $\mathrm{mgP} \mathrm{L}^{-1}$ ) & 0.073 & 0.029 & 1.451 & 0.001 & $* *$ & ns & $* *$ \\
\hline Particulate phosphorus (Ppart; $\mathrm{mgP} \mathrm{L}^{-1}$ ) & 0.153 & 0.043 & 2.018 & 0.004 & ns & $* *$ & $* *$ \\
\hline Total phosphorus (TP; $\mathrm{mgP} \mathrm{L}^{-1}$ ) & 0.226 & 0.052 & 2.121 & 0.009 & $*$ & $* *$ & $* *$ \\
\hline Chorophyll-a (Chl-a; $\left.\mathrm{mg} \mathrm{m}^{-3}\right)$ & 25.3 & 3.9 & 84.3 & 1.0 & ** & $* *$ & $* *$ \\
\hline Carotene $\left(\mathrm{mg} \mathrm{m}^{-3}\right)$ & 11.2 & 1.8 & 42.7 & 1.0 & ** & $* *$ & $* *$ \\
\hline Inorganic carbon (TIC; $\mathrm{mgC} \mathrm{L}^{-1}$ ) & 29.90 & 1.43 & 53.05 & 12.84 & $*$ & ns & $* *$ \\
\hline Dissolved organic carbon (DOC; $\mathrm{mgC} \mathrm{L}^{-1}$ ) & 5.16 & 0.45 & 12.02 & 1.32 & $* *$ & $* *$ & $* *$ \\
\hline Total organic carbon $\left(\mathrm{TOC} ; \mathrm{mgC} \mathrm{L}^{-1}\right)$ & 5.91 & 0.54 & 13.94 & 1.94 & ** & $* *$ & $* *$ \\
\hline Total carbon $\left(\mathrm{TC} ; \mathrm{mgC} \mathrm{L}^{-1}\right)$ & 35.82 & 1.48 & 59.76 & 22.33 & ns & $*$ & $* *$ \\
\hline Alkalinity $(\mathrm{meq} \mathrm{L}-1$ ) & 2.49 & 0.12 & 4.42 & 1.07 & $*$ & ns & $* *$ \\
\hline
\end{tabular}

The nitrogen and phosphorus levels of the rivers to the wetland were taken as reference values to evaluate the balance of nutrients (Table 2). The assessment of the average nutrient concentration achieved in the wetland indicated that $16 \%$ of the sampling points had TN concentrations above $10 \mathrm{mg} \mathrm{N} \mathrm{L}^{-1}$ and $90 \%$ exceeded $2 \mathrm{mg} \mathrm{N} \mathrm{L}^{-1}$, whereas $4 \%$ of the sites had TP concentrations higher than $1 \mathrm{mg} \mathrm{P} \mathrm{L}^{-1}$ and $61 \%$ exceeded $0.1 \mathrm{mg} \mathrm{P} \mathrm{L}^{-1}$ (Table 3). Analyzing the results according to the aquatic habitats, none of the rivers sampled exceeded an average TN concentration of $10 \mathrm{mg} \mathrm{N} \mathrm{L}^{-1}$ and an average TP concentration of 
$1 \mathrm{mg} \mathrm{P} \mathrm{L}{ }^{-1}$ (Tables 2 and 3), although the Turia River had TN concentrations higher than $5 \mathrm{mg} \mathrm{N} \mathrm{L}^{-1}$ (Table 2). Regarding the irrigation channels, $21 \%$ and $72 \%$ exceeded by one order of magnitude the average concentrations of TN and TP reached by the Jucar River (Table 2). In addition, $21 \%$ of the irrigation channels studied exceeded TN concentrations of $10 \mathrm{mg} \mathrm{N} \mathrm{L}^{-1}$ and $69 \%$ had TP concentrations above $0.1 \mathrm{mg} \mathrm{P} \mathrm{L}^{-1}$ (Table 3). Finally, for the Albufera lake (and outlet canals), 100\% of the points had TN and TP concentrations higher than $2 \mathrm{mg} \mathrm{N} \mathrm{L}^{-1}$ and $0.05 \mathrm{mg} \mathrm{P} \mathrm{L}^{-1}$, respectively (Table 3).

Table 2. Average concentrations of TN and TP reached in the Turia, Magro and Jucar rivers during the rice cultivation period (May 2019-October 2019).

\begin{tabular}{ccc}
\hline \multicolumn{3}{c}{ TN and TP Concentrations in the Rivers Sampled } \\
\hline & Mean TN $\left(\mathbf{m g ~ N ~ L ~}^{-\mathbf{1}}\right)$ & Mean TP $\left(\mathbf{m g ~ P ~ L ~}^{-\mathbf{1}}\right)$ \\
\hline Turia River-Masía Traver & 5.66 & 0.01 \\
Turia River-La Presa & 5.44 & 0.02 \\
Magro River & 2.80 & 0.11 \\
Júcar River & 1.08 & 0.01 \\
\hline
\end{tabular}

Table 3. Percentages of TN and TP for the different studied aquatic systems respect to the limits referenced.

\begin{tabular}{|c|c|c|c|c|c|}
\hline \multicolumn{6}{|c|}{ \% Ecosystems According to Nutrients Levels * } \\
\hline \multicolumn{6}{|c|}{ Total Nitrogen (TN) } \\
\hline Habitats & $n$ Total & \multicolumn{2}{|c|}{$>\mathbf{1 0} \mathbf{m g N ~ L}^{-1}[73]$} & $>2 \mathrm{mgN} \mathrm{L}^{-1}[74]$ & $>\mathbf{0 . 6 5} \mathbf{m g N ~ L}_{[69]}^{-1}$ \\
\hline Global & 51 & \multicolumn{2}{|c|}{$16 \%$} & $90 \%$ & $100 \%$ \\
\hline River & 4 & \multicolumn{2}{|c|}{$0 \%$} & $75 \%$ & $100 \%$ \\
\hline Irrigation channel & 39 & \multicolumn{2}{|c|}{$21 \%$} & $90 \%$ & $100 \%$ \\
\hline Lake & 8 & \multicolumn{2}{|c|}{$0 \%$} & $100 \%$ & $100 \%$ \\
\hline \multicolumn{6}{|c|}{ Total Phosphorus (TP) } \\
\hline Habitats & $n$ Total & $>1 \mathbf{~ m g P ~ L}^{-1}[73]$ & $>\mathbf{0 . 1} \mathrm{mgP} \mathrm{L}^{-1}[63]$ & $>\mathbf{0 . 0 5} \mathrm{mgP} \mathrm{L}_{[75]}^{-1}$ & $>\underset{[68]}{>0.035 \mathrm{mgP} \mathrm{L}^{-1}}$ \\
\hline Global & 51 & $4 \%$ & $61 \%$ & $82 \%$ & $86 \%$ \\
\hline River & 4 & $0 \%$ & $25 \%$ & $25 \%$ & $75 \%$ \\
\hline Irrigation channel & 39 & $5 \%$ & $69 \%$ & $85 \%$ & $90 \%$ \\
\hline Lake & 8 & $0 \%$ & $38 \%$ & $100 \%$ & $100 \%$ \\
\hline
\end{tabular}

${ }^{*}$ Percentages obtained from the calculated averages of TN and TP.

\subsection{Spatial Mapping of the Variables}

None of the variables studied presented a normal distribution (Shapiro-Wilk test, $p<0.05$; Figure S1, Supplementary Material). There were significant differences in physicochemical and biological variables for the different irrigation zones in our study (PERMANOVA, $\mathrm{F}=8.973, p<0.001$ ). No significant differences were observed with respect to different aquatic habitats and agricultural activities (PERMANOVA, $p>0.05$ ).

Most of the variables studied had significant differences between the zoning groups independently (Kruskal-Wallis, $p<0.05$ ) (Table 1). Turbidity, $\mathrm{pH}$, nitrates, DON, TN, Ppart and TC did not differ significantly between the different aquatic habitats $(p>0.05)$ (Table 1). The lake group had the highest conductivity values and the highest concentration of pigments and organic carbon (Mann-Whitney post hoc tests, $p<0.05$ ). The irrigation channels group showed the highest values of NH4-N, nitrites nitrogen and phosphates (Mann-Whitney post hoc tests, $p<0.05$ ).

According to the agricultural activities, DN, SRP, TIC and alkalinity were the only variables that did not differ significantly $(p>0.05)$ (Table 1$)$. The rice group was associated with the highest concentrations of photosynthetic pigments and also differed statistically from the mosaic and fruit groups due to its having the highest values of conductivity, turbidity, organic matter and organic carbon (Mann-Whitney post hoc tests, $p<0.02$ ). In ad- 
dition, the rice and vegetable groups were those with higher concentrations of phosphorus compounds (Mann-Whitney post hoc tests, $p<0.05$ ).

Geographical average values of the physicochemical and biological variables of the water bodies were well identified using GIS layers (Figure 2). In the north of the natural park, the groups of the Huerta Oeste, Favara and Oro irrigation zones were related to higher concentrations of NH4-N and nitrite nitrogen (Mann-Whitney post hoc tests, $p<0.05$ ) (Figures 2 and 4). Turia River, Huerta Oeste and Favara were also the irrigation zones with the highest levels of nitrate nitrogen (Mann-Whitney post hoc tests, $p<0.02$ ). Furthermore, Oro was the group with the highest concentrations of organic matter and total carbon (Mann-Whitney post hoc tests, $p<0.05$ ) (Figures 2 and 4 ). Finally, turbidity, pH, DON, DN and TN did not differ significantly between irrigation zones $(p>0.05)$ (Table 1$)$.

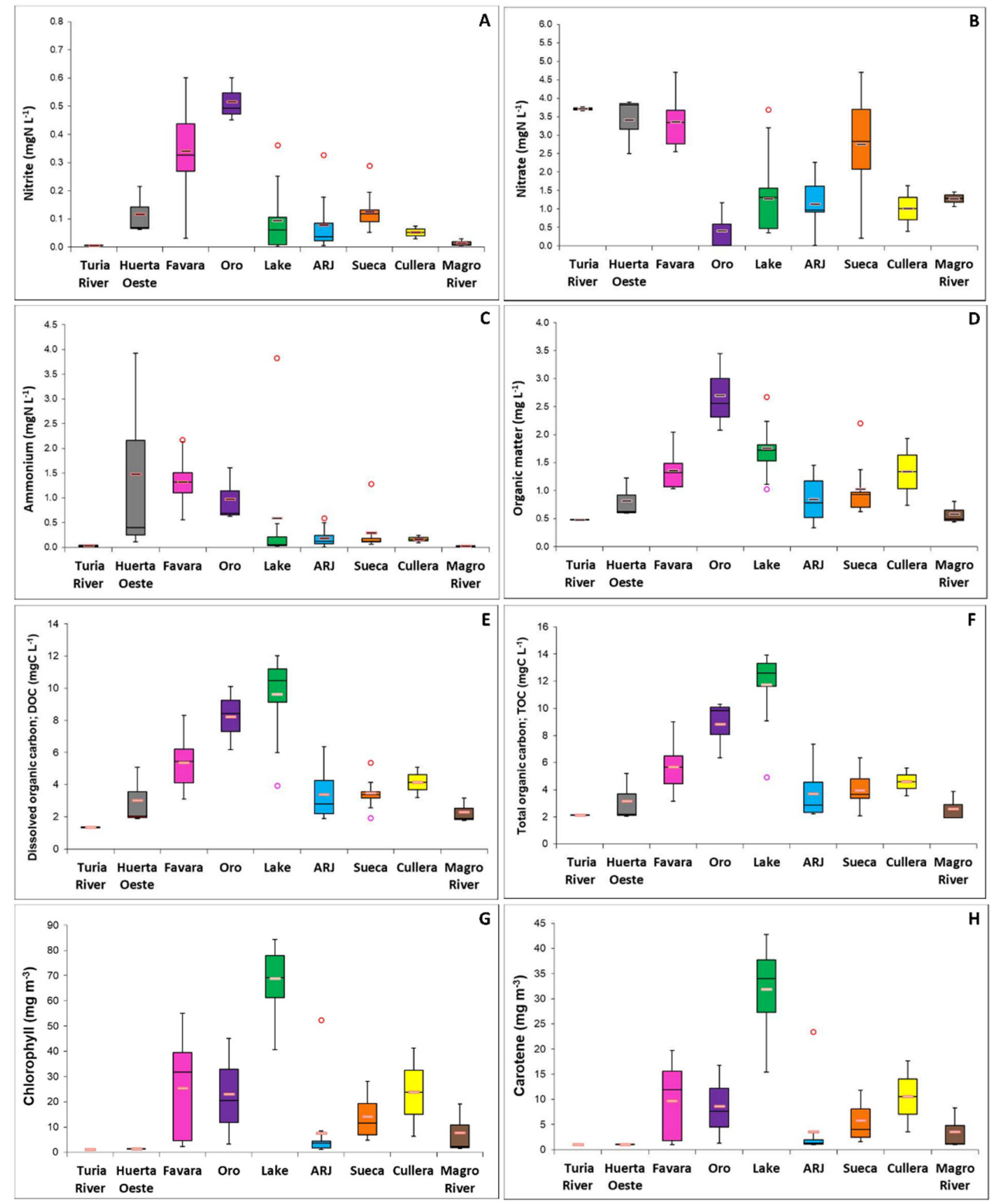

Figure 4. Some of the variables that showed statistical differences between the studied zones (KruskalWallis test, $p<0.05)$. Box-plots with medians, percentiles and outlier values. (A) Nitrite, (B) nitrate, (C) ammonium, (D) organic matter, (E) dissolved organic carbon, (F) total organic carbon, (G) chlorophyll $a,(\mathbf{H})$ carotene. 
When we used multivariate analyses for a spatial approach to the studied points, the two first axes of the PCA analysis explained $52 \%$ of the variability in the data. The first axis accounted for most of the variance (31\%) and clearly segregated the points sampled according to the concentrations of dissolved nutrients (especially phosphates, NH4-N and nitrite nitrogen). The second axis (21\%) distributed the water bodies according to the concentration of photosynthetic pigments and turbidity. The cluster analysis grouped the points mainly according to conductivity and chlorophyll concentration, and showed greater variability among the water systems, with the lowest values for both variables.

The main variables that correlated significantly $(p<0.05)$ and positively with phytoplanktonic chlorophyll $a$ were TOC $(r=0.768)$, DOC $(r=0.754)$, turbidity $(r=0.711)$ and organic matter $(r=0.650)$. All statistically significant correlations obtained for the main studied variables can be found in Supplementary Material, Figures S2 and S3.

\subsection{Trophic State and Ecological Potential of the Wetland}

The trophic status of water bodies was calculated first according to TP and Chl-a limits established by OECD [68]. Most of the aquatic systems (75\%) were classified as hypertrophic, $12 \%$ eutrophic and $12 \%$ mesotrophic. Only $2 \%$ presented meso-oligotrophic conditions (Figure 5A). Secondly, trophic state was also calculated according to TN limits established by Nürnberg [69]. Almost all aquatic ecosystems (94\%) were defined as hypertrophic, with the remaining $6 \%$ being eutrophic (Figure 5B).

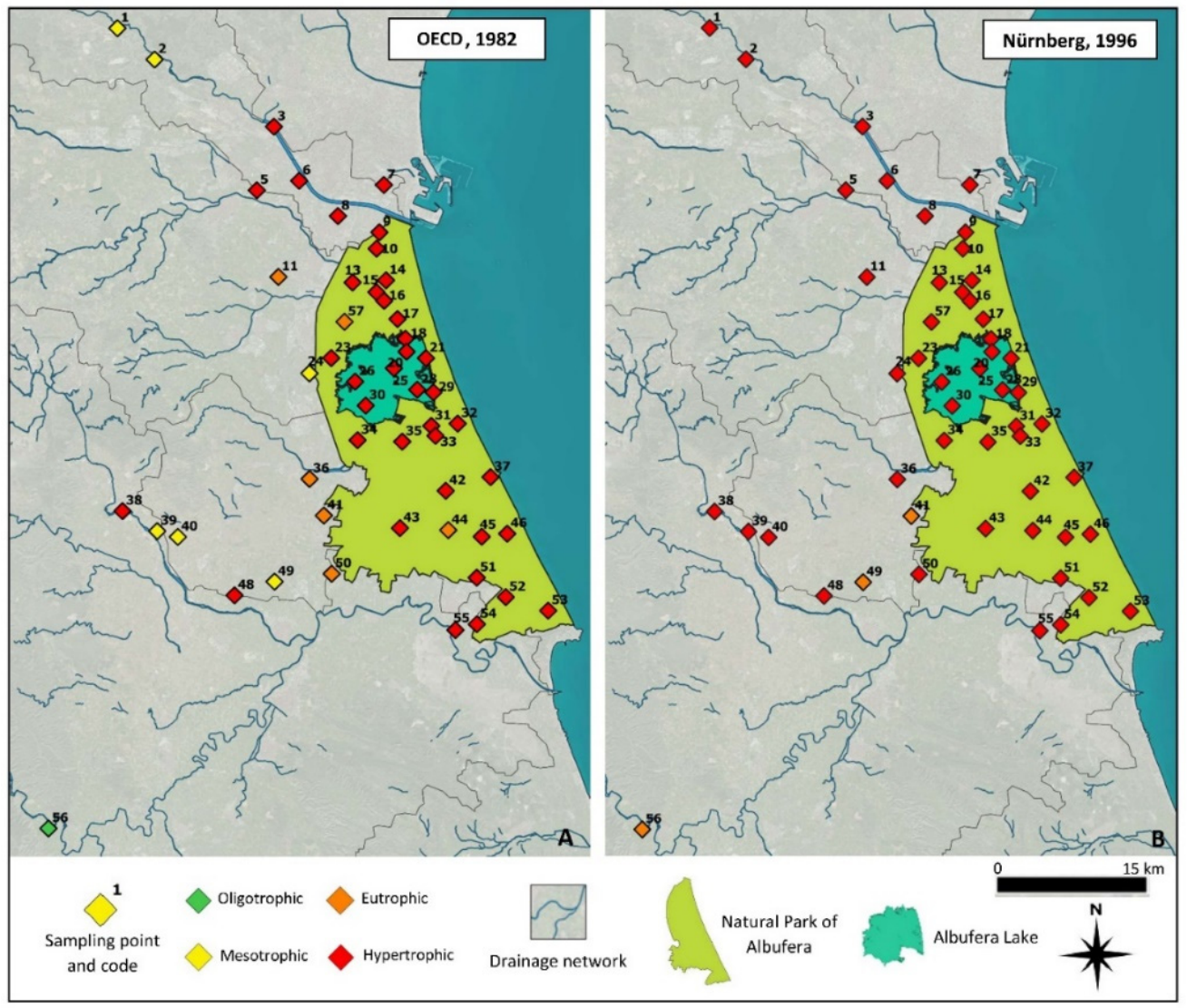

Figure 5. Study area with the spatial distribution of the sampling points classified according to their trophic status. (A) Evaluation according to OECD [68], (B) evaluation according to Nürnberg [69]. Base image: OrtoPNOA 2018 CC-BY 4.0 scne.es.

In relation to the ecological potential, 39\% of the water systems had the worst quality category of "bad" ecological potential, followed by $6 \%$ and $25 \%$ of the sites classified with "poor" and "moderate" ecological potential, respectively. Only a small percentage 
of $14 \%$ of the aquatic systems had a "high" ecological potential (Figure 6 and Figure S4, Supplementary Material).

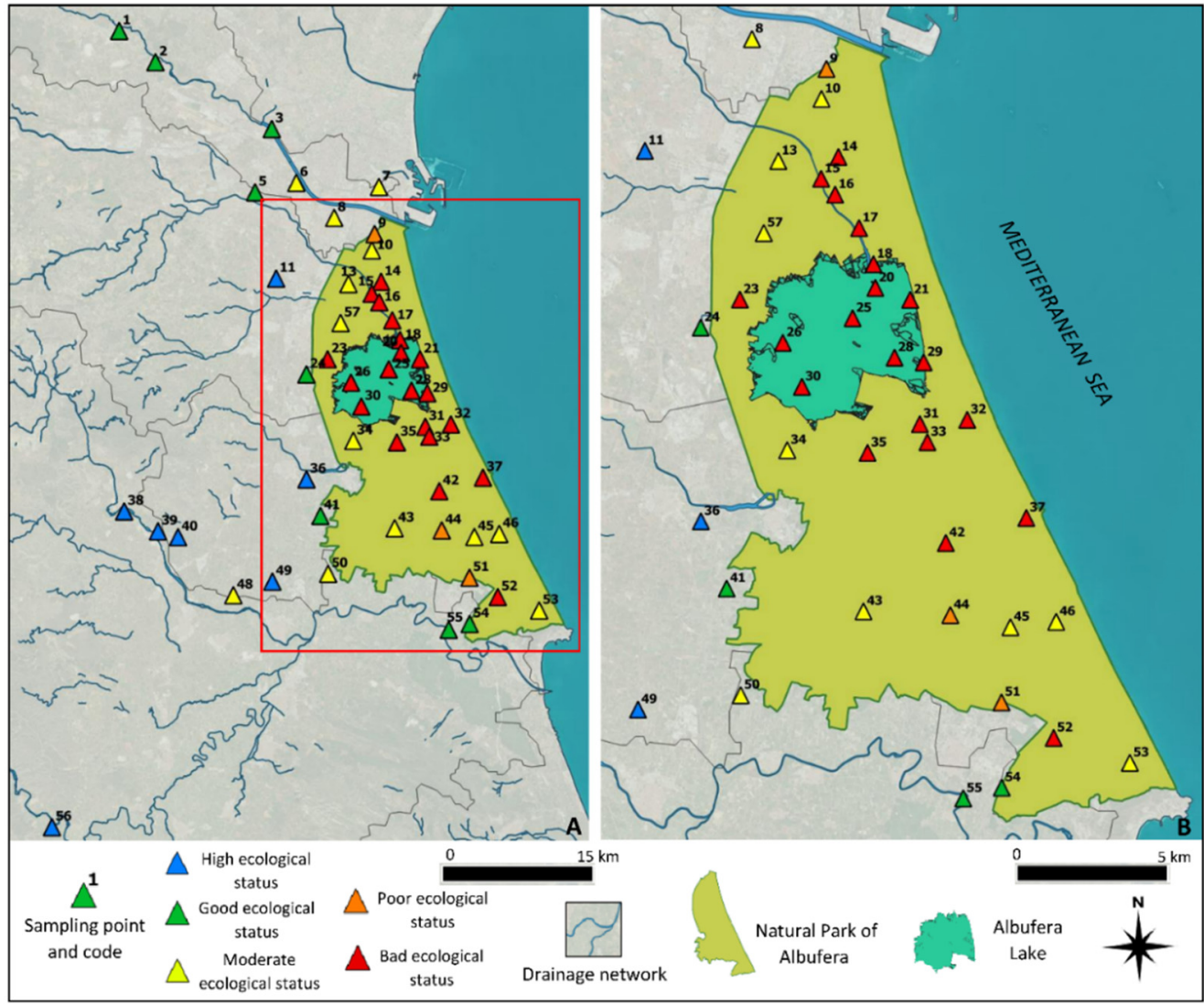

Figure 6. Study area and spatial distribution of the sampling points classified according to their ecological potential [24,70]. Results for (A) entire study area, (B) natural park area. Base image: OrtoPNOA 2018 CC-BY 4.0 scne.es.

Ecological potential was also assessed according to the different grouping criteria for aquatic ecosystems. Analyzing the water systems according to their water typologies, $59 \%$ of the sampling points located inside the natural park (categorized as L-T18-HM) had a "bad" ecological status, $9 \%$ presented a "poor" status and 26\% a "moderate" status. The sampling points located in the north of the study area (classified as R-T14) generally presented the worst ecological potential compared to those located in the south (classified as R-T17). According to the aquatic habitats, $100 \%$ of lake sampling points had a "bad" ecological potential. The irrigation channels group was represented by all categories and globally had a "poor" ecological potential. The river group was the group with the best quality, with a "good" ecological potential (50\% "high" and 50\% "good"). According to the different agricultural activities, the groups with the best global ecological potential were fruit crops and mosaic ("good"), whereas rice was the group with the worst quality ("bad"). Finally, in relation to the irrigation zones the groups with the best global ecological potential were Magro and Jucar ("high" and "good", respectively). The irrigation zones with the worst water quality were Favara, Oro, ARJ and Cullera, with a "poor" ecological potential. The percentages obtained from these analyses are shown in the Supplementary Material, Figure S4.

\section{Discussion}

In this study, the analysis of the physicochemical and biological variables of the different aquatic systems allowed us to evaluate the effect of agriculture and the irrigation water management, the wetland heterogeneity and the locations with a higher pollution 
impact according to the different human activities. In the study wetland, the cultivation of rice severely modulates water management and affected water $\mathrm{pH}$ and conductivity. The average conductivity of the aquatic systems found during this study defines this Mediterranean wetland as brackish with a moderate marine influence due the water management for agriculture. This is similar to the results reported by Soria et al. [76] in a specific study on the conductivity of Lake Albufera, with certain oscillations due to fluvial contributions.

The second effect observed due to agriculture in the wetland was the decrease in water turbidity, microalgae concentrations and levels of some nutrients, mainly affecting the lake at the end of the rice cultivation as a consequence of drainage of the rice fields before harvesting. At this period, rapid flushing of the system has also been reported, together with negative consequences for the water quality of the nearby coastal sea [51,52,77].

An interesting result of our study is that the system is continuously overloaded with nutrients during the whole rice cultivation period and the water discharges from the main rivers are too poor to contribute positively to the water quality of this coastal ecosystem. The average levels of TN and TP clearly indicate the impact of nutrient loadings in the wetland. About $16 \%$ and $4 \%$ of the sampling points exceeded the concentration limits of TN and TP, respectively, established by the legislation that regulates the discharges of treated urban wastewater in sensitive areas [73] (Table 3). More specifically, all the rivers studied, with the exception of the Jucar River, presented TN concentrations above the recommended limit [74] and all of them were eutrophic (Tables 2 and 3). When we analyzed the irrigation channels, $21 \%$ and $5 \%$ exceeded the TN and TP limits established by law and TP was even $69 \%$ higher than the recommended values [63].

Therefore, the obtained results show a nutrient-rich hydrographic network, where the entry of good quality water is not guaranteed. Furthermore, it is confirmed that the concentrations of nutrients present in the lake interfere with the recovery process of its biological richness. For instance, $90 \%$ and $82 \%$ of the water bodies studied exceeded the levels of TN and TP recommended for the recovery of submerged aquatic plants, which are key species required to shift the trophic states of shallow lakes [74,75]. The intensive uses of pesticides in the park also prevents colonization by submerged plants [78]. Interestingly, the average concentrations of dissolved nutrients in the wetland greatly exceeded those reached in the Mar Menor lagoon (Murcia, Spain) during the break phase of 2016-2017 [79]. In contrast, dissolved nutrients were lower than those attained in the main streams feeding the Doñana National Park, which is also affected by intensive agriculture [80].

The trophic status and ecological potential clearly showed the severe degradation of the wetland water systems. About $59 \%$ of the sampling points located inside the natural park had a "bad" ecological status and almost all sampling points (94\%) were hypertrophic. The level of TN in the wetland is one order of magnitude higher than the limit for a eutrophic system $\left(650 \mu \mathrm{g} \mathrm{N} \mathrm{L}^{-1}\right.$ vs. $\left.6300 \mu \mathrm{g} \mathrm{N} \mathrm{L}^{-1}\right)$. In terms of the ecological potential, the natural park's water bodies are classified as poor, especially its lake and the surrounding ditches (Figure 6). In regard to photosynthetic pigment levels, the average chlorophyll concentration in the wetland exceeds the limit established by the OECD [68] to describe a water body as hypertrophic ( $25.3 \mathrm{vs.} 25.0 \mathrm{mg} \mathrm{m}^{-3}$ ), which is remarkable, considering that this value includes all the different aquatic habitats studied. Although the maximum values were reached in the lake points, it is relevant to indicate that in several irrigation ditches the concentration of microalgae exceeded $50 \mathrm{mg} \mathrm{m}^{-3}$. This eutrophication in irrigation systems is similar to the levels detected in the three sub-catchments that feed the Doñana marsh [80]. As a comparison, in the artificial Lake Nasser (Egypt) fed by the Nile River, chlorophyll levels never exceeded $12 \mathrm{mg} \mathrm{m}^{-3}$, representing a very different system, free from the impact of agriculture [81]. Algal biomass in our study wetland was related to turbidity, DOC and TOC (Supplementary Material, Figure S2). Turbidity in lake Albufera can be also related to punctual precipitations [82] and sediment resuspension by wind [83]. In particular, a positive gradient of organic carbon and microalgae was observed, which 
starts in the north area of the Natural Park (nearby Pinedo I and II treatment plants and the Rambla de Torrent) and reaches the lake (Figure 2).

Mapping by different approaches the heterogeneity of the Natural Park of the Albufera has showed the complexity of this agroecosystem. The results show clear spatial differences in the water quality between the northern and southern aquatic systems. The north part has a greater influence of the metropolitan area of Valencia, wastewater treatment plants and industry pollution. The southern part is more affected by the extension of agriculture (mainly paddy fields). The evaluation of the ecological potential by areas provided further information about the irrigation sectors and the reuse of wastewater for agricultural activities.

The digital covers provided by QGIS were used to integrate the results obtained from the analytical analyses and allowed a detailed spatial assessment of the aquatic ecosystems of the wetland and part of the river catchment area. Firstly, the already rich nutrient waters in the irrigation channels are mixed and enriched by effluents from different wastewater treatment plants (WWTPs), especially those located in the north. The water taken from the River Turia circulates, mixed with effluents from various WWTPs and industrial treatment plants $[45,84]$. The WWTPs of Quart de Benager and Pinedo had the maximum values of NH4-N and nitrite nitrogen, whereas the maximum nitrate nitrogen and TP values were also found in an irrigation ditch of this zone (Favara, Figures 2 and 4). The pollution with $\mathrm{TP}$ was also punctual in different irrigation sectors. The maximum TN values (exceeding $14 \mathrm{mg} \mathrm{N} \mathrm{L}^{-1}$ ) were found mainly in the northwest of the lake, in irrigation ditches used for fruit and rice crops (Figure 4), but there were also some points of high dissolved organic nitrogen in the south (Figures 2 and 4). The diffuse and punctual discharges of nitrogen and phosphorus affected to the entire wetland. It is relevant that no significant differences were observed between agricultural activities, suggesting that the environmental impact depended on the water management in the wetland.

The multivariate statistical study of the irrigation sectors corroborated the location of the sites for dissolved nutrients in the northern part of the wetland (Turia River and up to the Huerta Oeste, Favara and Oro sectors). The latter two sectors and the Albufera Lake also accumulated the highest levels of organic matter, DOC and TOC (Figure 5). All these sectors are characterized by the reuse of treated wastewaters in the rice fields during the cultivation period [85]. The results pointed out that the quality of the effluents from the WWTPs is deficient in removing nutrients [45-48] and additionally can also be rich in emerging contaminants [48-50]. Overall, it seems inappropriate to use effluents from these WWTPs for agriculture in the Natural Park of the Albufera. As a possible practical solution, hybrid treatments could be included during the secondary treatment phase of the WWTPs, which keep activated sludge and biofilms in the same reactor, ensuring a higher nutrient removal efficiency [86]. More innovative proposals such as the inoculation of microalgae associated with $\mathrm{ZnO}$ nanoparticles into the bioreactor, or the installation of an osmotic dynamic membrane bioreactor/nanofiltration (OsMBR/NF) system, can be considered for the near future $[87,88]$. With a successful reduction of the nutrient levels, the use of the WWTP effluents to flood the rice fields could be considered, with no ecological risk to the Albufera lake or to the rest of the water bodies.

The Mediterranean Spanish coastal systems seem to be severely impacted by agriculture and the use of the limited water resources, which has become especially complicated in relation to rice crops, for example, in the Albufera Natural Park and the Ebro Delta [89,90]. In the Doñana National Park, the loss of water quality was related in equal parts to industrial and urban pressures (WWTPs) and also to rice cultivation [80,91]. In the Mar Menor, nitrates derived from irrigation water in the orchards shifted a whole marine ecosystem in a very short period [92]. Furthermore, in recent years other studies focusing on water quality and the correct management of Mediterranean coastal wetlands have reported the fragility and complexity of these ecosystems when they are impacted by agriculture $[11,19,38,93,94]$. 


\section{Conclusions}

In the present study, we evaluated the current ecological status of the Natural Park of Albufera, one of the main Spanish coastal wetlands, taking into account the anthropogenic impacts derived from agriculture, water management and the connectivity of the irrigation network. The results show that the aquatic ecosystems of the wetland are in eutrophic conditions, with poor ecological potential. The wetland is nutrient (phosphorus and nitrogen)-overloaded during the entire rice cultivation period. The input into the wetland of good quality water is deficient, since the river network already contains high levels of nutrients and pollutants, especially in the northern area, where, in addition, the poor water quality from the main river is mixed with inappropriate effluents from WWTPs.

The extensive spatial study carried out allowed the mapping of the problematic points of pollution. These locations should become focuses of attention for environmental measures. We could not help but question the sustainability of the intensive rice cultivation in the wetland. This is a reasonable concern when considering climate change scenarios.

The impact of agriculture and the water management intensively affected the lake Albufera within the Natural Park, modulating most of its studied variables. This is a sensitive habitat of flux and the accumulation of pollutants could end up in the Mediterranean Sea. The connectivity of the hydrological system in this coastal ecosystem implies a complex cause-and-effect effect from the water catchment areas to the sea.

For all these reasons, the implementation of appropriate environmental measures is considered necessary for the Albufera Natural Park. This could involve extensive and continuous monitoring of the human uses and activities in the wetland and taking action on the sources of pollution. It is important to emphasize the need to increase the ecological inputs provided by fluvial systems with higher water quality and the importance of optimizing WWPTs. It seems inappropriate to use effluents from WWTPs for agriculture in the Natural Park of the Albufera. Finally, it is clear from the results that the recovery of an adequate ecological potential requires more restrictive nutrient thresholds and legislation. The information gathered in the Albufera Park can help to optimize the global study and management of coastal Mediterranean wetlands.

Supplementary Materials: The following supporting information can be downloaded at: https: / / www.mdpi.com/article/10.3390/agronomy12020486/s1. Table S1: Classification of sampling points according to their corresponding aquatic habitat, the agricultural activity carried out in its vicinity, the irrigation zone and the water body typology. Water body typology established according to the Water Framework Directive [24] and Decree 1/2016 (reference: BOE-A-2016-439); Table S2: Limit of detection (LOD) and limit of quantification (LOQ) of the main physico-chemical and biological variables determined in the laboratory, studied in the water bodies during rice cultivation (May to October 2019); Table S3: Mean, standard error, maximum and minimum values of the physico-chemical and biological variables studied in the wetland for the two sampling campaigns at the beginning and the end of rice cultivation (see Section 2 for more details); Figure S1: Frequency distribution and adjustment curves of turbidity, $\mathrm{pH}$, conductivity, total nutrients, organic matter and phytoplanktonic chlorophyll for the values of the two sampling periods; Figure S2: Significant linear relationships $(p<0.01)$ of the study variables related to chlorophyll (A) and nitrogen (B), together with the values of Spearman's correlation coefficient; Figure S3: Significant linear relationships ( $p$ $<0.01$ ) of the study variables related to phosphorus (A) and carbon (B), together with the values of Spearman's correlation coefficient; Figure S4: Percentages of the ecological potential for the different aquatic ecosystems and typologies [24,70]. Results for (A) the global study of the wetland and for the distinct water body typologies, (B) considering aquatic habitats, (C) according to agricultural activities and (D) according to irrigation zones.

Author Contributions: Conceptualization: S.R. and L.V.-H.; methodology: L.V.-H.; formal analysis: L.V.-H., S.R. and J.S.; investigation: L.V.-H., S.R. and J.S.; data curation: L.V.-H., S.R. and J.S.; writing-original draft preparation: L.V.-H.; writing—review and editing: S.R. and J.S.; visualization: L.V.-H.; supervision: S.R. and J.S. All authors have read and agreed to the published version of the manuscript. 
Funding: This research was funded by the Spanish Ministry of Science, Innovation and Universities and the European Regional Development Fund (ERDF) through the project WETANPACK (grant number RTI2018-097158-B-C31) and by the Generalitat Valenciana through the project ANTROPOCEN@ (PROMETEO/2018/155).

Institutional Review Board Statement: Not applicable.

Informed Consent Statement: Not applicable.

Data Availability Statement: Not applicable.

Acknowledgments: We are grateful to all our collaborators for their valuable help and support during field and laboratory work, especially to our colleges from the CIDE-UV-GV Institute during sampling. We also thank to the Sara Calvo for her help during the research and the Valencia Environmental Agency for the facilities given during the study.

Conflicts of Interest: The authors declare no conflict of interest. The funders had no role in the design of the study; in the collection, analyses, or interpretation of data; in the writing of the manuscript, or in the decision to publish the results.

\section{References}

1. Chiaia-Hernández, A.C.; Günthardt, B.F.; Frey, M.P.; Hollender, J. Unravelling Contaminants in the Anthropocene Using Statistical Analysis of Liquid Chromatography-High-Resolution Mass Spectrometry Nontarget Screening Data Recorded in Lake Sediments. Environ. Sci. Technol. 2017, 51, 12547-12556. [CrossRef] [PubMed]

2. Yuan, X.; Zhang, M.; Wang, L.; Zhou, T. Understanding and Seasonal Forecasting of Hydrological Drought in the Anthropocene. Hydrol. Earth Syst. Sci. 2017, 21, 5477-5492. [CrossRef]

3. Mitsch, W.J.; Gosselink, J.G. Wetlands, 4th ed.; John Wiley \& Sons: Hoboken, NJ, USA, 2007.

4. Moss, B. Fresh Waters, Climate Change and UK Nature Conservation. Freshw. Rev. 2014, 7, 25-75. [CrossRef]

5. Raymond, P.A.; Hartmann, J.; Lauerwald, R.; Sobek, S.; McDonald, C.; Hoover, M.; Butman, D.; Striegl, R.; Mayorga, E.; Humborg, C. Global Carbon Dioxide Emissions from Inland Waters. Nature 2013, 503, 355-359. [CrossRef]

6. Romo, S.; Soria, J.; Olmo, C.; Flor, J.; Calvo, S.; Ortells, R.; Armengol, X. Nutrients and Carbon in Some Mediterranean Dune Ponds. Hydrobiologia 2016, 782, 97-109. [CrossRef]

7. Shaltout, K.; El-Bana, M.; Galal, T. Coastal Lakes as Hot Spots for Plant Diversity in Egypt. In Egyptian Coastal Lakes and Wetlands: Part II; Negm, A.M., Beck, M.A., Abdel-Fattah, S., Eds.; Springer: Berlin/Heidelberg, Germany, 2017; pp. $129-146$.

8. Were, D.; Kansiime, F.; Fetahi, T.; Cooper, A.; Jjuuko, C. Carbon Sequestration by Wetlands: A Critical Review of Enhancement Measures for Climate Change Mitigation. Earth Syst. Environ. 2019, 3, 327-340. [CrossRef]

9. Gardner, R.C.; Finlayson, C.M. Global Wetland Outlook: State of the World's Wetlands and Their Services to People 2018; Secretariat of the Ramsar Convention: Gland, Switzerland, 2018.

10. Pascual-Aguilar, J.A.; Andreu Pérez, V.; Gimeno-García, E.; Picó, Y. Current Anthropogenic Pressures on Agro-Ecological Protected Coastal Wetlands. Sci. Total Environ. 2015, 503, 190-199. [CrossRef]

11. Leberger, R.; Geijzendorffer, I.R.; Gaget, E.; Gwelmami, A.; Galewski, T.; Pereira, H.M.; Guerra, C.A. Mediterranean Wetland Conservation in the Context of Climate and Land Cover Change. Reg. Environ. Chang. 2020, 20, 67. [CrossRef]

12. Myers, N.; Mittermeier, R.A.; Mittermeier, C.G.; da Fonseca, G.A.B.; Kent, J. Biodiversity Hotspots for Conservation Priorities. Nature 2000, 403, 853-858. [CrossRef]

13. Cuttelod, A.; García, N.; Malak, D.A.; Temple, H.J.; Stuart, S.N. The Mediterranean: A Biodiversity Hotspot under Threat. In Wildlife in a Changing World: An Analysis of the 2008 IUCN Red List of Threatened Species; Vié, J.C., Hilton-Taylor, C., Stuart, S.N., Eds.; IUCN: Gland, Switzerland, 2009.

14. Li, Y.; Zhu, X.; Sun, X.; Wang, F. Landscape Effects of Environmental Impact on Bay-Area Wetlands under Rapid Urban Expansion and Development Policy: A Case Study of Lianyungang, China. Landsc. Urban Plan. 2010, 94, 218-227. [CrossRef]

15. García-Ruiz, J.M.; López-Moreno, J.I.; Vicente-Serrano, S.M.; Lasanta-Martínez, T.; Beguería, S. Mediterranean Water Resources in a Global Change Scenario. Earth-Sci. Rev. 2011, 105, 121-139. [CrossRef]

16. Guiot, J.; Cramer, W. Climate Change: The 2015 Paris Agreement Thresholds and Mediterranean Basin Ecosystems. Science 2016, 354, 465-468. [CrossRef] [PubMed]

17. Klausmeyer, K.R.; Shaw, M.R. Climate Change, Habitat Loss, Protected Areas and the Climate Adaptation Potential of Species in Mediterranean Ecosystems Worldwide. PLOS ONE 2009, 4, e6392. [CrossRef]

18. Mariotti, A.; Zeng, N.; Yoon, J.-H.; Artale, V.; Navarra, A.; Alpert, P.; Li, L.Z. Mediterranean Water Cycle Changes: Transition to Drier 21st Century Conditions in Observations and CMIP3 Simulations. Environ. Res. Lett. 2008, 3, 044001. [CrossRef]

19. Geijzendorffer, I.; Chazée, L.; Gaget, E.; Galewski, T.; Guelmami, A.; Perennou, C.; Davidson, N.; McInnes, R. Mediterranean Wetlands Outlook 2: Solutions for Sustainable Mediterranean Wetlands; Secretariat of the Ramsar Convention: Arles, France, 2018.

20. Jégou, A.; Sanchis-Ibor, C. The Opaque Lagoon. Water Management and Governance in l'Albufera de València Wetland (Spain). Limnetica 2019, 38, 503-515. [CrossRef] 
21. Pascual-Aguilar, J.A.; Campo, J.; Meneu, S.N.; Gimeno-García, E.; Andreu, V. Analysis of Existing Water Information for the Applicability of Water Quality Indices in the Fluvial-Littoral Area of Turia and Jucar Rivers, Valencia, Spain. Appl. Geogr. 2019, 111, 102062. [CrossRef]

22. EEC. Council Directive 91/676/EEC, of 12 December 1991, concerning the protection of waters against pollution caused by nitrates from agricultural sources. Off. J. Eur. Comm. 1991, L375, 1-8. Available online: https://eur-lex.europa.eu/legal-content/ EN/TXT/?uri=OJ:L:1991:375:TOC (accessed on 10 May 2021).

23. EEC. Council Directive 91/271/EEC, of 21 May 1991, concerning urban wastewater. Off. J. Eur. Comm. 1991, L135, 40-52 Available online: https:/ / eur-lex.europa.eu/legal-content/EN/TXT/?uri=OJ:L:1991:135:TOC (accessed on 10 May 2021).

24. EC. Council Directive 2000/60/EC, of 23 October 2000, establishing a framework for Community action in the field of water policy. Off. J. Eur. Comm. 2000, L327, 1-73. Available online: https:/ / eur-lex.europa.eu/legal-content/EN/TXT/?uri=OJ:L:2000:327:TOC (accessed on 9 May 2021).

25. Carlson, R.E. A Trophic State Index for Lakes. Limnol. Oceanogr. 1977, 22, 361-369. [CrossRef]

26. Li, B.; Yang, G.; Wan, R.; Hörmann, G. Dynamic Water Quality Evaluation Based on Fuzzy Matter-Element Model and Functional Data Analysis, a Case Study in Poyang Lake. Environ. Sci. Pollut. Res. 2017, 24, 19138-19148. [CrossRef] [PubMed]

27. Şener, Ş.; Şener, E.; Davraz, A. Evaluation of Water Quality Using Water Quality Index (WQI) Method and GIS in Aksu River (SW-Turkey). Sci. Total Environ. 2017, 584-585, 131-144. [CrossRef]

28. Sun, W.; Xia, C.; Xu, M.; Guo, J.; Sun, G. Application of Modified Water Quality Indices as Indicators to Assess the Spatial and Temporal Trends of Water Quality in the Dongjiang River. Ecol. Indic. 2016, 66, 306-312. [CrossRef]

29. Escribano-Francés, G.; Quevauviller, P.; San Martín González, E.; Vargas Amelin, E. Climate Change Policy and Water Resources in the EU and Spain. A Closer Look into the Water Framework Directive. Environ. Sci. Policy 2017, 69, 1-12. [CrossRef]

30. Hestir, E.L.; Brando, V.E.; Bresciani, M.; Giardino, C.; Matta, E.; Villa, P.; Dekker, A.G. Measuring Freshwater Aquatic Ecosystems: The Need for a Hyperspectral Global Mapping Satellite Mission. Remote Sens. Environ. 2015, 167, 181-195. [CrossRef]

31. Dominguez, J.A. Estudio de La Calidad Del Agua de Las Lagunas de Gravera Mediante Teledetección. Doctoral Thesis, Universidad de Alcalá, Alcalá de Henares, Spain, 2003.

32. Osorio, R.J.; Linhoss, A.; Dash, P. Evaluation of Marsh Terraces for Wetland Restoration: A Remote Sensing Approach. Water 2020, 12, 336. [CrossRef]

33. Sòria-Perpinyà, X.; Vicente, E.; Urrego, P.; Pereira-Sandoval, M.; Tenjo, C.; Ruíz-Verdú, A.; Delegido, J.; Soria, J.M.; Peña, R.; Moreno, J. Validation of Water Quality Monitoring Algorithms for Sentinel-2 and Sentinel-3 in Mediterranean Inland Waters with In Situ Reflectance Data. Water 2021, 13, 686. [CrossRef]

34. Vera-Herrera, L.; Soria, J.; Pérez, J.; Romo, S. Long-Term Hydrological Regime Monitoring of a Mediterranean Agro-Ecological Wetland Using Landsat Imagery: Correlation with the Water Renewal Rate of a Shallow Lake. Hydrology 2021, 8, 172. [CrossRef]

35. Foltête, J.-C.; Vuidel, G. Using Landscape Graphs to Delineate Ecologically Functional Areas. Landsc. Ecol. 2017, 32, 249-263. [CrossRef]

36. Wang, X.; Zhang, J.; Babovic, V.; Gin, K.Y.H. A Comprehensive Integrated Catchment-Scale Monitoring and Modelling Approach for Facilitating Management of Water Quality. Environ. Model. Softw. 2019, 120, 104489. [CrossRef]

37. Roche, K.R.; Aubeneau, A.F.; Xie, M.; Aquino, T.; Bolster, D.; Packman, A.I. An Integrated Experimental and Modeling Approach to Predict Sediment Mixing from Benthic Burrowing Behavior. Environ. Sci. Technol. 2016, 50, 10047-10054. [CrossRef] [PubMed]

38. Çevirgen, S.; Elwany, H.; Pesce, M.; Zirino, A. Managing Nutrient Pollution in Venice Lagoon (Italy): A Practical Tool for Assessment of Water Quality. Sustain. Water Resour. Manag. 2020, 6, 33. [CrossRef]

39. Elshemy, M.; Zeidan, B.; Assar, W. Water Quality Mitigation Scenarios for Burullus Coastal Lake, Egypt. In Estuaries and Coastal Zones in Times of Global Change; Nguyen, K.D., Guillou, S., Gourbesville, P., Thiébot, J., Eds.; Springer: Berlin, Germany, 2020; pp. 89-110.

40. Shalby, A.; Elshemy, M.; Zeidan, B.A. Assessment of Climate Change Impacts on Water Quality Parameters of Lake Burullus, Egypt. Egypt. Environ. Sci. Pollut. Res. 2020, 27, 32157-32178. [CrossRef]

41. Generalitat Valenciana. Parc Natural de 1'Albufera. 2015. Available online: http://www.parquesnaturales.gva.es/es/web/pn-1albufera (accessed on 10 January 2021)

42. Pascual-Aguilar, J.A. Cambios de Usos del Suelo y Régimen Hídrico en la Rambla de Poyo y el Barranc de Carraixet. Doctoral Thesis, Universitat de València, Valencia, Spain, 2004.

43. Gil Olcina, A.; Rico, A. El Problema Del Agua En La Comunidad Valenciana; Fundación de la Comunidad Valenciana Agua y Progreso: Valencia, Spain, 2007; ISBN 84-611-5317-0.

44. Pascual-Aguilar, J.A.; Andreu, V.; Vázquez, P.; Picó, Y. Presence and Spatial Distribution of Emerging Contaminants (Drugs of Abuse) in Protected Agroecological Systems (L'Albufera de Valencia Coastal Wetland, Spain). Environ. Earth Sci. 2014, $71,31-37$. [CrossRef]

45. Martín, M.; Hernández-Crespo, C.; Andrés-Doménech, I.; Benedito-Durá, V. Fifty Years of Eutrophication in the Albufera Lake (Valencia, Spain): Causes, Evolution and Remediation Strategies. Ecol. Eng. 2020, 155, 105932. [CrossRef]

46. Aznar, R.; Sánchez-Brunete, C.; Albero, B.; Moreno-Ramón, H.; Tadeo, J.L. Pyrethroids Levels in Paddy Field Water under Mediterranean Conditions: Measurements and Distribution Modelling. Paddy Water Environ. 2017, 15, 307-316. [CrossRef]

47. Campo, J.; Masiá, A.; Picó, Y.; Farré, M.; Barceló, D. Distribution and Fate of Perfluoroalkyl Substances in Mediterranean Spanish Sewage Treatment Plants. Sci. Total Environ. 2014, 472, 912-922. [CrossRef] 
48. Lorenzo, M.; Campo, J.; Morales Suárez-Varela, M.; Picó, Y. Occurrence, Distribution and Behavior of Emerging Persistent Organic Pollutants (POPs) in a Mediterranean Wetland Protected Area. Sci. Total Environ. 2019, 646, 1009-1020. [CrossRef]

49. Sadutto, D.; Andreu, V.; Ilo, T.; Akkanen, J.; Picó, Y. Pharmaceuticals and Personal Care Products in a Mediterranean Coastal Wetland: Impact of Anthropogenic and Spatial Factors and Environmental Risk Assessment. Environ. Pollut. 2021, $271,116353$. [CrossRef]

50. Sadutto, D.; Andreu, V.; Ilo, T.; Akkanen, J.; Picó, Y. Dataset of Pharmaceuticals and Personal Care Products in a Mediterranean Coastal Wetland. Data Brief 2021, 36, 106934. [CrossRef]

51. Romo, S.; Villena, M.-J.; Sahuquillo, M.; Soria, J.M.; Giménez, M.; Alfonso, T.; Vicente, E.; Miracle, M.R. Response of a Shallow Mediterranean Lake to Nutrient Diversion: Does It Follow Similar Patterns as in Northern Shallow Lakes? Freshw. Biol. 2005, 50, 1706-1717. [CrossRef]

52. Soria, J.; Vicente, E.; Miracle, M. The Influence of Flash Floods on the Limnology of the Albufera of Valencia Lagoon (Spain). SIL Proc. 2000, 27, 2232-2235. [CrossRef]

53. Soria, J.M.; Vicente, E. Estudio de Los Aportes Hídricos al Parque Natural de La Albufera de Valencia. Limnetica 2002, 21, 105-115. [CrossRef]

54. Soria, J.; Vera-Herrera, L.; Calvo, S.; Romo, S.; Vicente, E.; Sahuquillo, M.; Sòria-Perpinyà, X. Residence Time Analysis in the Albufera of Valencia, a Mediterranean Coastal Lagoon, Spain. Hydrology 2021, 8, 37. [CrossRef]

55. Arévalo, C. Introducción al Estudio de Los Cladóceros Del Plankton de La Albufera de Valencia; Anales del Instituto General y Técnico de Valencia, 1; Imprenta Hijos de Francisco Vives Mora: Valencia, Spain, 1916.

56. Blanco, C. Estudio de La Contaminación de La Albufera de Valencia y de Los Efectos de Dicha Contaminación Sobre La Fauna y Flora Del Lago. Doctoral Thesis, Universitat de València, Valencia, Spain, 1974.

57. Dafauce Ruiz, C. La Albufera de Valencia: Un Estudio Piloto. In Monografías; Instituto para la Conservación de la Naturaleza (ICONA): Valencia, España, 1975; Volume 4, pp. 1-127.

58. Pardo, L. La Albufera de Valencia. Biología de Las Aguas Continentales II; Instituto Forestal de Investigaciones y Experiencias: Madrid, Spain, 1942.

59. Onandia, G.; Gudimov, A.; Miracle, M.R.; Arhonditsis, G. Towards the Development of a Biogeochemical Model for Addressing the Eutrophication Problems in the Shallow Hypertrophic Lagoon of Albufera de Valencia, Spain. Ecol. Inform. 2015, 26, 70-89. [CrossRef]

60. Segura, J.B.M.; Ibor, C.S.; Vázquez, A.V. Regadío y Saneamiento Urbano En l'Albufera de València: Análisis Cartográfico. Cuad. Geogr. 1999, 65, 61-80.

61. Romo, S.; Soria, J.; Fernández, F.; Ouahid, Y.; Barón-Solá, Á. Water Residence Time and the Dynamics of Toxic Cyanobacteria. Freshw. Biol. 2013, 58, 513-522. [CrossRef]

62. Copernicus Land Monitoring Service. CORINE Land Cover 2018. Available online: https://land.copernicus.eu/pan-european/ corine-land-cover/clc2018 (accessed on 30 December 2020).

63. Mondría, M. Estudio Para El Desarrollo Sostenible de L'Albufera de Valencia. Síntesis de Los Estudios Técnicos; Confederación Hidrográfica Del Júcar: Madrid, Spain, 2004.

64. APHA. Standard Methods for the Examination of Water and Wastewater; General Books LLC: Memphis, TN, USA, 2011.

65. UNE-EN 1484:1998; Water Analysis-Guidelines for the Determination of Total Organic Carbon (TOC) and Dissolved Organic Carbon (DOC). European Committee for Standardization: Bruxelles, Belgium, 1997.

66. Murphy, J.; Riley, J.P. A Modified Single Solution Method for the Determination of Phosphate in Natural Waters. Anal. Chim. Acta 1962, 27, 31-36. [CrossRef]

67. Jeffrey, E.; Humphrey, G.F. New Spectrophotometric Equations for Determining Chlorophyll a, b, c1 and c2 in Higher Plants, Algae and Natural Phytoplankton. Biochem. Physiol. 1975, 167, 91-194. [CrossRef]

68. OECD. Organisation for Economic Co-Operation and Development. 1982. Available online: http://www.oecd.org/ (accessed on 10 March 2021).

69. Nürnberg, G.K. Trophic State of Clear and Colored, Soft-and Hardwater Lakes with Special Consideration of Nutrients, Anoxia, Phytoplankton and Fish. Lake Reserv. Manag. 1996, 12, 432-447. [CrossRef]

70. Decret 817/2015. BOE. Real Decreto 817/2015, de 11 de Septiembre, Por El Que Se Establecen Los Criterios de Seguimiento y Evaluación Del Estado de Las Aguas Superficiales y Las Normas de Calidad Ambiental. Available online: https:/ /www.boe.es/ diario_boe/txt.php?id=BOE-A-2015-9806 (accessed on 12 April 2021).

71. AVAMET Meteorological Historical Database. Available online: https:/ / www.avamet.org/ (accessed on 10 February 2021).

72. Hammer, Ø.; Harper, D.A.; Ryan, P.D. PAST: Paleontological Statistics Software Package for Education and Data Analysis. Palaeontol. Electron. 2001, 4, 9.

73. Decret 509/1996. BOE. Real Decreto 509/1996, de 15 de Marzo, de Desarrollo Del Real Decreto-Ley 11/1995, de 28 de Diciembre, Por El Que Se Establecen Las Normas Aplicables al Tratamiento de Las Aguas Residuales Urbanas. Available online: https: / / www.boe.es/diario_boe/txt.php?id=BOE-A-1996-7159 (accessed on 10 April 2021).

74. Jeppesen, E.; Søndergaard, M.; Meerhoff, M.; Lauridsen, T.L.; Jensen, J.P. Shallow Lake Restoration by Nutrient Loading Reduction-Some Recent Findings and Challenges Ahead. Hydrobiologia 2007, 584, 239-252. [CrossRef]

75. Romo, S.; Miracle, M.R.; Villena, M.; Rueda, J.; Ferriol, C.; Vicente, E. Mesocosm Experiments on Nutrient and Fish Effects on Shallow Lake Food Webs in a Mediterranean Climate. Freshw. Biol. 2004, 49, 1593-1607. [CrossRef] 
76. Soria, J.; Romo, S.; Vera-Herrera, L.; Calvo, S.; Sòria-Perpinyà, X. Evolución de la conductividad en la Albufera de Valencia entre 1985 y 2018. Limnetica 2021, 40, 223-232. [CrossRef]

77. Sòria-Perpinyà, X. Remote Sensing Application for the Study of Rapid Flushing to Remediate Eutrophication in Shallow Lagoons (Albufera of Valencia). Hydrobiologia 2019, 829, 125-132. [CrossRef]

78. Calvo, S.; Romo, S.; Soria, J.; Picó, Y. Pesticide Contamination in Water and Sediment of the Aquatic Systems of The Natural Park of the Albufera of Valencia (Spain) during the Rice Cultivation Period. Sci. Total Environ. 2021, 774, 145009. [CrossRef]

79. Pérez-Ruzafa, A.; Campillo, S.; Fernández-Palacios, J.M.; García-Lacunza, A.; García-Oliva, M.; Ibañez, H.; Navarro-Martínez, P.C.; Pérez-Marcos, M.; Pérez-Ruzafa, I.M.; Quispe-Becerra, J.I.; et al. Long-Term Dynamic in Nutrients, Chlorophyll a, and Water Quality Parameters in a Coastal Lagoon During a Process of Eutrophication for Decades, a Sudden Break and a Relatively Rapid Recovery. Front. Mar. Sci. 2019, 6, 26. [CrossRef]

80. Paredes Losada, I. Anthropogenic Pressures and Eutrophication in the Doñana Marsh and Its Watershed. Doctoral Thesis, Universidad de Sevilla, Sevilla, Spain, 2020.

81. Rizk, R.; Juzsakova, T.; Cretescu, I.; Rawash, M.; Sebestyén, V.; Le Phuoc, C.; Kovács, Z.; Domokos, E.; Rédey, Á.; Shafik, H. Environmental Assessment of Physical-Chemical Features of Lake Nasser, Egypt. Environ. Sci. Pollut. Res. 2020, 27, 20136-20148. [CrossRef]

82. Sebastiá-Frasquet, M.-T.; Aguilar-Maldonado, J.A.; Santamaría-Del-Ángel, E.; Estornell, J. Sentinel 2 Analysis of Turbidity Patterns in a Coastal Lagoon. Remote Sens. 2019, 11, 2926. [CrossRef]

83. Soria, J.; Jover-Cerdá, M.; Gómez, J. Influence of Wind on Suspended Matter in the Water of the Albufera of Valencia (Spain). J. Mar. Sci. Eng. 2021, 9, 343. [CrossRef]

84. Mondría, M. Infraestructuras y Eutrofización en L'Albufera de València. El Modelo Cabhal. Doctoral Thesis, Universidad Politécnica de Valencia, Valencia, Spain, 2010.

85. Vazquez-Roig, P.; Andreu, V.; Blasco, C.; Picó, Y. SPE and LC-MS/MS Determination of 14 Illicit Drugs in Surface Waters from the Natural Park of L'Albufera (València, Spain). Anal. Bioanal. Chem. 2010, 397, 2851-2864. [CrossRef] [PubMed]

86. Rodríguez-Hernández, L.; Esteban-García, A.L.; Lobo, A.; Temprano, J.; Álvaro, C.; Mariel, A.; Tejero, I. Evaluation of a Hybrid Vertical Membrane Bioreactor (HVMBR) for Wastewater Treat-ment. Water Sci. Technol. 2012, 65, 1109-1115. [CrossRef] [PubMed]

87. Vasistha, S.; Khanra, A.; Rai, M.P. Influence of Microalgae-ZnO Nanoparticle Association on Sewage Wastewater towards Efficient Nutrient Removal and Improved Biodiesel Application: An Integrated Approach. J. Water Process. Eng. 2021, $39,101711$. [CrossRef]

88. Nguyen, N.C.; Nguyen, H.T.; Duong, H.C.; Chen, S.-S.; Le, H.Q.; Duong, C.C.; Trang, L.T.; Chen, C.-K.; Nguyen, P.D.; Bui, X.T.; et al. A Breakthrough Dynamic-Osmotic Membrane Bioreactor/Nanofiltration Hybrid System for Real Municipal Wastewater Treatment and Reuse. Bioresour. Technol. 2021, 342, 125930. [CrossRef]

89. Cerralbo, P.; F-Pedrera Balsells, M.; Mestres, M.; Fernandez, M.; Espino, M.; Grifoll, M.; Sanchez-Arcilla, A. Use of a Hydrodynamic Model for the Management of Water Renovation in a Coastal System. Ocean Sci. 2019, 15, 215-226. [CrossRef]

90. Mañosa, S.; Mateo, R.; Guitart, R. A Review of the Effects of Agricultural and Industrial Contamination on the Ebro Delta Biota and Wildlife. Environ. Monit. Assess. 2001, 71, 187-205. [CrossRef]

91. Camacho-Muñoz, D.; Martín, J.; Santos, J.; Aparicio, I.; Alonso, E. Distribution and Risk Assessment of Pharmaceutical Compounds in River Sediments from Doñana Park (Spain). Water Air Soil Pollut. 2013, 224, 1665. [CrossRef]

92. Álvarez-Rogel, J.; Jiménez-Cárceles, F.; Nicolás, C.E. Phosphorus and Nitrogen Content in the Water of a Coastal Wetland in the Mar Menor Lagoon (SE Spain): Relationships with Effluents from Urban and Agricultural Areas. Water Air Soil Pollut. 2006, 173, 21-38. [CrossRef]

93. Day, J.W.; Ibáñez, C.; Pont, D.; Scarton, F. Status and Sustainability of Mediterranean Deltas: The Case of the Ebro, Rhône, and Po Deltas and Venice Lagoon. In Coasts and Estuaries; Wolanski, E., Day, J.W., Elliot, M., Ramachandran, R., Eds.; Elsevier: Amsterdam, The Netherlands, 2019; pp. 237-249.

94. Tórz, A.; Bonisławska, M.; Rybczyk, A.; Nędzarek, A.; Tański, A. Susceptibility to Degradation, the Causes of Degradation, and Trophic State of Three Lakes in North-West Poland. Water 2020, 12, 1635. [CrossRef] 